\title{
Factors associated with the homicides of women who are victims of violence
}

\author{
Fatores associados aos homicídios de mulheres vítimas de violência \\ Factores relacionados a los homicidios de mujeres víctimas de violencia
}

\author{
Sheyla Carvalho de Barros' \\ ORCID: 0000-0001-5399-0296 \\ Dayane da Rocha Pimentel" \\ ORCID: 0000-0002-9863-134X \\ Conceição Maria de Oliveira'"' \\ ORCID: 0000-0002-2220-5782 \\ Cristine Vieira do Bonfim 1,1V \\ ORCID: 0000-0002-4495-9673
}

'Universidade Federal de Pernambuco. Recife, Pernambuco, Brazil. "Fundação Oswaldo Cruz, Instituto Aggeu Magalhães. Recife, Pernambuco, Brazil.

I' Secretaria de Saúde do Recife. Recife, Pernambuco, Brazil.

" Fundação Joaquim Nabuco. Recife, Pernambuco, Brazil.

How to cite this article:

Barros SC, Pimentel DR, Oliveira CM, Bonfim CV. Factors associated with the homicides of women who are victims of violence. Rev Bras Enferm. 2021;74(5):e20200630. https://doi.org/10.1590/0034-7167-2020-0630

Corresponding author:

Sheyla Carvalho de Barros

E-mail: sheyla.barross@gmail.com

EDITOR IN CHIEF: Dulce Barbosa ASSOCIATE EDITOR: Hugo Fernandes

Submission: 09-06-2020

Approval: $12-30-2020$

\begin{abstract}
Objectives: to identify factors associated with homicides in women who had prior notification of violence in the state of Pernambuco, 2011 to 2016. Methods: a transversal, quantitative and observational study, guided by the STROBE tool, with data of homicides of women obtained from the Mortality Information System; and of violence against women, from the Grievance Notification Information System. The logistic regression model was used to verify the factors associated with the homicides. Results: there were 32,308 cases of violence against women and 1,162 homicides. The chances of homicide were higher for women: victims of physical violence ( 2.39 times more), aggression by object of court (2.32 times more), aggression by firearm ( 6 times more), and when there was a recurrence of violence (3.82 times more). Conclusions: association of physical violence, agression by object of court, aggression by firearm, recurrence of violence with homicides of women in the state of Pernambuco was found.

Descriptors: Homicide; Violence Against Women; Health Information Systems; Vital Statistics; Nursing.
\end{abstract}

\section{RESUMO}

Objetivos: identificar os fatores associados aos homicídios em mulheres que tinham notificação prévia de violência, no estado de Pernambuco, 2011 a 2016. Métodos: estudo transversal, quantitativo e observacional, norteado pela ferramenta STROBE, com dados de homicídios de mulheres obtidos do Sistema de Informações sobre Mortalidade; e de violência contra mulheres, do Sistema de Informação de Agravos de Notificação. Para verificação de fatores associados aos homicídios, empregou-se o modelo de regressão logística. Resultados: registraram-se 32.308 casos de violência contra mulher e 1.162 homicídios. As chances de homicídio foram maiores para mulheres: vítimas de violência física (2,39 vezes mais), agressão por objeto de corte (2,32 vezes mais), agressão por arma de fogo ( 6 vezes mais) e quando houve reincidência da violência ( 3,82 vezes mais). Conclusões: encontrou-se associação da violência física, agressão por objeto de corte, agressão por arma de fogo, reincidência da violência com os homicídios de mulheres no estado de Pernambuco.

Descritores: Homicídio; Violência Contra a Mulher; Sistemas de Informação em Saúde; Estatísticas Vitais; Enfermagem.

\section{RESUMEN}

Objetivos: identificar factores relacionados a los homicidios en mujeres que tenían notificación previa de violencia, en Pernambuco, 2011 a 2016. Métodos: estudio transversal, cuantitativo y observacional, norteado por STROBE, con datos de homicidios de mujeres obtenidos del Sistema de Informaciones sobre Mortalidad; y de violencia contra mujeres, del Sistema de Información de Agravios de Notificación. Para verificación de factores relacionados a los homicidios, se empleó el modelo de regresión logística. Resultados: registraron 32.308 casos de violencia contra mujer y 1.162 homicidios. Las chances de homicidio fueron mayores para mujeres: víctimas de violencia física (2,39 veces más), agresión por objeto de corte (2,32 veces más), agresión por arma de fuego ( 6 veces más) y cuando hube reincidencia de la violencia ( 3,82 veces más). Conclusiones: encontró relación de la violencia física, agresión por objeto de corte, agresión por arma de fuego, reincidencia de la violencia con los homicidios de mujeres en Pernambuco.

Descriptores: Homicidio; Violencia Contra la Mujer; Sistemas de Información en Salud; Estadísticas Vitales; Enfermería. 


\section{INTRODUCTION}

Violence against women is a global problem of public health and human rights violations, affects all classes and is part of the 2030 Agenda for Sustainable Development in the effort to achieve gender equality ${ }^{(1-3)}$. Violence against women" is defined as all acts of gender-based behavior that may result in psychic, sexual and psychological harm or suffering to women, or cause coercion or arbitrary deprivation of liberty, occurring in public or private life $\mathrm{i}^{(1,4-5)}$. Consists of a social construction based on a social consensus on the roles and rights of men and women ${ }^{(1)}$.

The most common forms of violence against women are domestic violence as well as sexual abuse and violence ${ }^{(1,6)}$. Recognized that these two types affect women disproportionately more and are an expression of the power inequality between men and women, that is, a form of gender-based violence ${ }^{(1)}$.

It is estimated that one in three women worldwide will suffer physical and/or sexual violence by an intimate partner during their lifetime. This reflects gender inequality and discrimination against women ${ }^{(7)}$. Gender inequality is considered a basic structural factor for intimate partner violence in male and female couples $^{(8)}$. It is understood that this inequality creates unbalanced power structures in which men have authority over women and employ violence to maintain the hierarchy ${ }^{(8)}$. In addition, these structures limit women from accessing resources and making decisions that can reduce the risk of violence ${ }^{(8-9)}$.

Homicide represents the most extreme form of violence. For gender-related homicides, the term "femicide" refers to the murder of women or girls because of their role and status as women. Femicide does not represent isolated cases or sporadic episodes of violence, but rather a structural and social situation, a cultural phenomenon deeply rooted in customs and mentalities ${ }^{(10)}$.

In 2017, a total of 87,000 women were intentionally killed, with an overall female homicide rate estimated at 2.3 per 100,000 women. Approximately $58 \%$ of these women were killed by intimate partners or family members, which means that 137 women in the world are killed by a member of their own family every day. In addition, more than one-third $(30,000)$ of the women killed intentionally were victims of their partner or former intimate partner. When an intimate partner is implicated in the homicide, $82 \%$ of the victims are women ${ }^{(11)}$.

In Brazil, in 2018, 4,519 women were victims of homicides, a rate of 4.3 per 100,000 women. Between 2017 and 2018, there was a $9.3 \%$ reduction in the country's homicide rate for women ${ }^{(12)}$. In the state of Pernambuco, it was 4.9 per 100,000 women, being above the rate in Brazil and among the states with the highest rates ${ }^{(12)}$. Likewise, research on the estimates of femicides in Brazil positioned the state among the highest rates and the second in the Northeast Region ${ }^{(13)}$.

There is little research on violence against women in the Northeast Region; and recognizing that there are significant regional variations in female homicide rates and that social, economic and cultural factors influence violence, it is justified to conduct this study in the state of Pernambuco.

\section{OBJECTIVES}

To identify factors associated with homicides in women who had prior notification of violence in the state of Pernambuco, 2011 to 2016.

\section{METHODS}

\section{Ethical aspects}

This study was approved by the Research Ethics Committee involving Human Beings of the Federal University of Pernambuco.

\section{Design, time and study location}

It is a cross-sectional, quantitative and observational study, guided by the STROBE tool. It was carried out with data from the Mortality Information System - MIS (2012 to 2016) and the Grievance Notification Information System - SINAN (2011 to 2016). In the year the survey was conducted, the last year with data finalized was 2016. It is understood that vital statistics systems close two years behind the current year. This study was carried out in the state of Pernambuco, Northeast Region of Brazil, which has 185 municipalities. It is divided into five Mesoregions and 12 Health Regions. According to the Brazilian Institute of Geography and Statistics 2016 population estimate, the total population is $9,410,336$ inhabitants. Women are in the majority, 4,873,140, equivalent to $52 \%$ of the total ${ }^{(14)}$.

\section{Population}

The study population was composed of women, from ten years of age, victims of homicides that occurred between 2012 and 2016. Included were the deaths registered in the MIS, codified in Chapter XX, "External causes of morbidity and mortality (codes X85 to Y09 - Aggressions), from the International Classification of Diseases and Problems Related to Health (also known as International Classification of Diseases - ICD 10); and the cases of women victims of violence notified in the SINAN between 2011 and 2016.

\section{Study protocol}

The data of the homicides were obtained from the MIS, which has the Declaration of Death as its instrument of collection. The notifications of violence against women were obtained from the SINAN, which are registered based on the notification form and individual investigation of interpersonal and self-provoked violence.

A probabilistic linkage of the MIS and SINAN databases was performed. The probabilistic analysis is useful when the unique identifier does not exist. This type of linkage combines the evidence by means of a number of identifiers, representing the probability of two registers belonging to the same person ${ }^{(15-16)}$. The variables considered were "name", "mother's name" and "date of birth". The RecLink III program was used for the linkage application, which was executed in steps that started by cleaning the databases. In the next step, the variables: name, age, date of birth, address, neighborhood and municipality of residence were standardized - followed by the subdivision of the fields and creation of the phonetic fields. The subsequent step was the blocking of records, which subdivides the files according to the indexing key, formed based on the matching variables. Record comparisons are restricted to concordance of the value of the 
keys. True and dubious pairs were manually reviewed. After the linkage, it was possible to identify, among the homicides, which had previous records of violence in SINAN.

For the selection of the analyzed variables, the completeness proportion was considered, being included those with "good" classification. Completeness was given by the proportion of ignored and blank fields, with the following parameters: good $(\geq 75.1 \%)$; regular (50.1\% to $75.0 \%)$; low (25.1\% to $50.0 \%)$; and very low (s $25.0 \%)^{(17)}$. According to these parameters, the following variables (with their respective completeness) were excluded from the analysis: schooling (50.7\%); family relationship with the aggressor (71.2\%); known aggressor (70.9\%) and unknown aggressor (70.9\%). Although the variable race/color also presented regular completeness for the SINAN data, in relation to the homicide data (MIS) the completeness was higher than 90\%; for this reason, it was chosen to keep this variable in the analysis.

The homicides of women were considered as a dependent variable, and the independent variables were related to the victims (age, race/color, and marital situation) and the previous violence (zone of residence, zone of occurrence, place of occurrence, physical violence, psychological violence, sexual violence, reoccurrence of violence, aggression by bodily force/spam, aggression by hanging, aggression by blunt/cutting/perforating object, aggression by cutting object, aggression by substance/ hot object, aggression by poisoning, aggression by firearm and victim/aggressor-partner relationship).

\section{Analysis of results and statistics}

The analysis was divided into three stages: univariate, bivariate and multivariate. The first concerns the general profile of the sample, while the second seeks to find relationships between the explanatory variables and the response variable (homicide) to be inserted in the last step.

For inferential statistical analysis (bivariate and multivariate), Pearson's chi-square test for independence, the odds ratio (by the maximum likelihood method) and logistic regression (univariate and multivariate) were used. The latter is a statistical technique that aims to produce, in front of a set of observations, a model that allows the prediction of values taken by a categorical variable, especially binary, based on a series of continuous and/or categorical explanatory variables. In the model, the probability of homicide occurrence was estimated according to the predictor variables. For a variable to be adopted in the estimation of the model, it must be significant in the bivariate analysis. The stepwise method was adopted for the selection of variables remaining in the model if $\mathrm{p}<0.05$. The interpretation of the coefficients is based on the odds ratio; and the quality of the adjustment, measured by Hosmer and Lemeshow's test. The R program, version 3.5.0, was used for the statistical analysis.

\section{RESULTS}

In the period, 32,308 notifications of violence against women were registered, with predominance in the age group of over 20 years old (70.8\%), black/parents (81.6\%) and unmarried (73.3\%). The majority lived in urban areas (87.9\%), where most of the occurrences also occurred (86.7\%). The most reported violence was physical (73\%), through body strength (58.4\%); violence occurred at home $(67.8 \%)$, with partner/ex-partner aggressors (48.9\%). Some women presented recurrence of violence (4.6\%). For those who reported violence again, the majority had two notifications, up to eight (Table 1).

Table 1 - Characteristics of notifications of violence against women, Pernambuco, Brazil, 2011-2016

\begin{tabular}{|c|c|c|}
\hline Variables & $\mathbf{n}$ & $\%$ \\
\hline \multicolumn{3}{|l|}{ Age $(n=32,308)$} \\
\hline 10 to 20 years & 9,442 & 29.2 \\
\hline More than 20 years & 22,866 & 70.8 \\
\hline \multicolumn{3}{|l|}{ Race/color $(n=23,133)$} \\
\hline Black/Brown & 18,879 & 81.6 \\
\hline Not black & 4,254 & 18.4 \\
\hline \multicolumn{3}{|l|}{ Marital status $(n=30,692)$} \\
\hline Not married & 22,500 & 73.3 \\
\hline Married & 8,192 & 26.7 \\
\hline \multicolumn{3}{|c|}{ Zone of residence $(n=29,408)$} \\
\hline Rural/periurban & 3,553 & 12.1 \\
\hline Urban & 25,855 & 87.9 \\
\hline \multicolumn{3}{|c|}{ Zone of occurrence $(n=24,722)$} \\
\hline Rural/periurban & 3,286 & 13.3 \\
\hline Urban & 21,436 & 86.7 \\
\hline \multicolumn{3}{|c|}{ Place of occurrence $(n=24,960)$} \\
\hline Public road or others & 8,035 & 32.2 \\
\hline Residency & 16,925 & 67.8 \\
\hline \multicolumn{3}{|c|}{ Physical violence $(n=29,622)$} \\
\hline No & 7,996 & 27.0 \\
\hline Yes & 21,626 & 73.0 \\
\hline \multicolumn{3}{|c|}{ Psychological violence $(n=26,311)$} \\
\hline No & 14,806 & 56.3 \\
\hline Yes & 11,505 & 43.7 \\
\hline \multicolumn{3}{|c|}{ Sexual violence $(n=25,988)$} \\
\hline No & 20,340 & 78.3 \\
\hline Yes & 5,648 & 21.7 \\
\hline \multicolumn{3}{|c|}{ Recurrence of violence $(n=32,308)$} \\
\hline No & 30,806 & 95.4 \\
\hline Yes & 1,502 & 4.6 \\
\hline \multicolumn{3}{|c|}{ Aggression by body strength/spasm $(n=27,599)$} \\
\hline No & 11,470 & 41.6 \\
\hline Yes & 16,129 & 58.4 \\
\hline \multicolumn{3}{|c|}{ Aggression by choking $(n=25,102)$} \\
\hline No & 24,209 & 96.4 \\
\hline Yes & 893 & 3.6 \\
\hline \multicolumn{3}{|c|}{$\begin{array}{l}\text { Aggression by blunt/cutting/perforating object } \\
(\mathrm{n}=25,270)\end{array}$} \\
\hline Não & 23,883 & 94.5 \\
\hline Sim & 1,387 & 5.5 \\
\hline \multicolumn{3}{|c|}{ Aggression by cutting object $(n=25,634)$} \\
\hline No & 22,720 & 88.6 \\
\hline Yes & 2,914 & 11.4 \\
\hline \multicolumn{3}{|c|}{ Aggression by substance/hot object $(n=25,108)$} \\
\hline No & 24,871 & 99.1 \\
\hline Yes & 237 & 0.9 \\
\hline \multicolumn{3}{|c|}{ Poisoning aggression $(n=25,105)$} \\
\hline No & 24,832 & 98.9 \\
\hline Yes & 273 & 1.1 \\
\hline \multicolumn{3}{|c|}{ Agression by firearm $(n=25,271)$} \\
\hline No & 23,695 & 93.8 \\
\hline Yes & 1,576 & 6.2 \\
\hline \multicolumn{3}{|c|}{$\begin{array}{l}\text { Victim/aggressor - partner/ex-partner relationship } \\
(n=24,261)\end{array}$} \\
\hline No & 12,397 & 51.1 \\
\hline Yes & 11,864 & 48.9 \\
\hline
\end{tabular}


Table 2 - Characteristics of female homicides, Pernambuco, Brazil, 2012-2016

\begin{tabular}{lcc}
\hline \multirow{2}{*}{ Variable } & \multicolumn{2}{c}{ Homicide } \\
& $\mathbf{n}$ & $\%$ \\
\hline Age $(\mathrm{n}=1,162)$ & & \\
$\quad$ 10 to 20 years & 244 & 21.0 \\
$\quad$ More than 20 years & 918 & 79.0 \\
Race/color $(\mathrm{n}=1,143)$ & & \\
$\quad$ Black/Brown & 1,006 & 88.0 \\
$\quad$ Not black & 137 & 12.0 \\
Marital status $(\mathrm{n}=1,015)$ & & \\
$\quad$ Not married & 910 & 89.7 \\
$\quad$ Married & 105 & 10.3 \\
Zone of occurrence $(\mathrm{n}=1,154)$ & & \\
$\quad$ Public road & 475 & 41.2 \\
$\quad$ Residence & 287 & 24.9 \\
$\quad$ Hospital/health services & 269 & 23.3 \\
$\quad$ Others & 123 & 10.7 \\
Cause of death ( $\mathrm{n}=1,158)$ & & \\
$\quad$ Firearm & 658 & 56.6 \\
$\quad$ Blunt/cutting/perforating object & 439 & 37.8 \\
$\quad$ Body strength & 49 & 4.2 \\
$\quad$ Others & 12 & 1.0 \\
\hline
\end{tabular}

There were 1,162 female homicide victims, most of whom were over 20 years old (79\%), black/black (88\%), and unmarried (89.7\%). Homicide occurred on the public highway (41.2\%) and by shooting a firearm (56.6\%) (Table 2 ).

In the bivariate analysis, the association of the occurrence of homicides with the variables "zone of residence", "physical violence", "sexual violence" and "recidivism of violence", "aggression by perforating object", "aggression by substance/object/hot" and "aggression by firearm", all statistically significant $(p<0.05)$, was evidenced (Table 3).

The chances of homicide were higher for women who suffered physical violence ( 2.39 times greater), aggression by cutting object(2.32 times greater), aggression by firearm (6.05 times greater), and when there was a recurrence of violence (more than one notification of violence) (3.82 times greater) (Table 4). The multivariate logistic regression model presented $p=0.99$ for the adjustment goodness test, not indicating divergences between the estimated and expected probabilities.

Table 3 - Characteristics of previous violence due to homicide, Pernambuco, Brazil, 2011-2016

\begin{tabular}{|c|c|c|c|c|c|c|c|c|c|}
\hline \multirow{3}{*}{ Variables } & \multicolumn{4}{|c|}{ Homicide } & \multirow{3}{*}{$\begin{array}{c}p \text { value } \\
\left(x^{2}\right)\end{array}$} & \multirow{3}{*}{$\begin{array}{c}\text { Gross } \\
\text { OR }\end{array}$} & \multirow{3}{*}{$\begin{array}{l}\text { Gross OR } \\
\text { (p value) }\end{array}$} & \multirow{3}{*}{$\begin{array}{c}\text { Adjusted } \\
\text { OR }\end{array}$} & \multirow{3}{*}{$\begin{array}{c}\text { Adjustec } \\
\text { OR } \\
\text { ( } p \text { value) }\end{array}$} \\
\hline & \multicolumn{2}{|c|}{ No } & \multicolumn{2}{|c|}{ Yes } & & & & & \\
\hline & $\mathbf{n}$ & $\%$ & $\mathbf{n}$ & $\%$ & & & & & \\
\hline \multicolumn{10}{|l|}{ Age } \\
\hline 10 to 20 years & 9,415 & 29.1 & 27 & 0.1 & 0.12 & 1.00 & & 1.00 & \\
\hline Over 20 years & 22,772 & 70.5 & 94 & 0.3 & & 1.44 & 0.11 & 1.44 & 0.10 \\
\hline Race/color & & & & & 0.21 & & & & \\
\hline White & 4,243 & 13.1 & 11 & 0.0 & & 1.00 & & 1.00 & \\
\hline Non white & 18,803 & 58.2 & 76 & 0.2 & & 1.56 & 0.21 & 1.56 & 0.17 \\
\hline Zone of residence & & & & & 0.02 & & & & \\
\hline Rural/periurban & 3,532 & 10.9 & 21 & 0.1 & & 1.00 & & 1.00 & \\
\hline Urban & 25,771 & 79.8 & 84 & 0.3 & & 0.55 & 0.02 & 0.55 & 0.01 \\
\hline Zone of occurence & & & & & 0.74 & & & & \\
\hline Rural/periurban & 3,274 & 10.1 & 12 & 0.0 & & 1.00 & & 1.00 & \\
\hline Urban & 21,369 & 66.1 & 67 & 0.2 & & 0.86 & 0.62 & 0.86 & 0.62 \\
\hline Place of occurence & & & & & 0.79 & & & & \\
\hline Public road or others & 8,007 & 24.8 & 28 & 0.1 & & 1.00 & & 1.00 & \\
\hline Residence & 16,871 & 52.2 & 54 & 0.2 & & 0.92 & 0.72 & 0.92 & 0.70 \\
\hline Physical violence & & & & & 0.00 & & & & \\
\hline No & 7,985 & 24.7 & 11 & 0.0 & & 1.00 & & 1.00 & \\
\hline Yes & 21,527 & 66.6 & 99 & 0.3 & & 3.34 & 0.00 & 3.34 & 0.00 \\
\hline Psychological violence & & & & & 0.24 & & & & \\
\hline No & 14,747 & 45.7 & 59 & 0.2 & & 1.00 & & 1.00 & \\
\hline Yes & 11,470 & 35.5 & 35 & 0.1 & & 0.76 & 0.21 & 0.76 & 0.21 \\
\hline Sexual violence & & & & & 0.01 & & & & \\
\hline No & 20,259 & 62.7 & 81 & 0.3 & & 1.00 & & 1.00 & \\
\hline Yes & 5,640 & 17.5 & 8 & 0.0 & & 0.36 & 0.00 & 0.35 & 0.01 \\
\hline Marital status & & & & & 0.62 & & & & \\
\hline Married & 8,159 & 25.3 & 33 & 0.1 & & 1.00 & & 1.00 & \\
\hline Not married & 22,420 & 69.4 & 80 & 0.3 & & 1.13 & 0.52 & 1.13 & 0.55 \\
\hline Recurrence of violence & & & & & 0.00 & & & & \\
\hline No & 30,700 & 95.0 & 106 & 0.3 & & 1.00 & & 1.00 & \\
\hline Yes & 1,487 & 4.6 & 15 & 0.1 & & 2.92 & 0.00 & 2.92 & 0.00 \\
\hline Aggression by body strength & & & & & 0.74 & & & & \\
\hline No & 11,428 & 35.4 & 42 & 0.1 & & 1.00 & & 1.00 & \\
\hline Yes & 16,075 & 49.8 & 54 & 0.2 & & 0.91 & 0.68 & 0.91 & 0.66 \\
\hline Aggression by choking & & & & & 0.14 & & & & \\
\hline No & 24,125 & 74.7 & 84 & 0.3 & & 1.00 & & 1.00 & \\
\hline Yes & 893 & 2.8 & 0 & 0.0 & & 0.00 & 0.08 & 0.00 & 0.97 \\
\hline Aggression by blunt/cutting/perforating object & & & & & 0.71 & & & & \\
\hline No & 23,803 & 73.7 & 80 & 0.2 & & 1.00 & & 1.00 & \\
\hline Yes & 13,81 & 4.3 & 6 & 0.0 & & 1.29 & 0.48 & 1.29 & 0.55 \\
\hline
\end{tabular}




\begin{tabular}{|c|c|c|c|c|c|c|c|c|c|}
\hline \multirow{3}{*}{ Variables } & \multicolumn{4}{|c|}{ Homicide } & \multirow{3}{*}{$\begin{array}{c}p \text { value } \\
\left(x^{2}\right)\end{array}$} & \multirow{3}{*}{$\begin{array}{c}\text { Gross } \\
\text { OR }\end{array}$} & \multirow{3}{*}{$\begin{array}{c}\text { Gross OR } \\
\text { (p value) }\end{array}$} & \multirow{3}{*}{$\begin{array}{c}\text { Adjusted } \\
\text { OR }\end{array}$} & \multirow{3}{*}{$\begin{array}{c}\text { Adjusted } \\
\text { OR } \\
\text { (p value) }\end{array}$} \\
\hline & \multicolumn{2}{|c|}{ No } & \multicolumn{2}{|c|}{ Yes } & & & & & \\
\hline & $\mathbf{n}$ & $\%$ & $\mathbf{n}$ & $\%$ & & & & & \\
\hline Aggression by cutting object & & & & & 0.00 & & & & \\
\hline No & 2,892 & 9.0 & 22 & 0.1 & & 1.00 & & 1.00 & \\
\hline Yes & 22,652 & 70.1 & 68 & 0.2 & & 2.53 & 0.00 & 2.53 & 0.00 \\
\hline Aggression by hot substance/ object & & & & & 0.00 & & & & \\
\hline No & 233 & 0.7 & 4 & 0.0 & & 1.00 & & 1.00 & \\
\hline Yes & 24,788 & 76.7 & 83 & 0.3 & & 5.13 & 0.01 & 5.13 & 0.00 \\
\hline Aggression by poisoning & & & & & 0.11 & & & & \\
\hline No & 270 & 0.8 & 3 & 0.0 & & 1.00 & & 1.00 & \\
\hline Yes & 24,748 & 76.6 & 84 & 0.3 & & 3.27 & 0.07 & 3.27 & 0.04 \\
\hline Aggression by firearm & & & & & 0.00 & & & & \\
\hline No & 1557 & 4.8 & 19 & 0.1 & & 1.00 & & 1.00 & \\
\hline Yes & 23,625 & 73.1 & 70 & 0.2 & & 4.12 & 0.00 & 4.12 & 0.00 \\
\hline Victim/aggressor - partner/ex-partner relationship & & & & & 0.51 & & & & \\
\hline No & 12,365 & 38.3 & 32 & 0.1 & & 1.00 & & & \\
\hline Yes & 11,827 & 36.6 & 37 & 0.1 & & 1.21 & 0.47 & 1.21 & 0.43 \\
\hline
\end{tabular}

Table 4 - Estimates of adjusted multivariate logistic regression model coefficients and reasons for chances of homicide, Pernambuco, Brazil, 2011-2016

\begin{tabular}{|c|c|c|c|c|c|c|c|}
\hline Coefficient & Estimate & Standard error & Value of $\mathbf{Z}$ & OR & \multicolumn{2}{|c|}{$95 \% \mathrm{IC}$} & $p$ value \\
\hline Intercept & -6.13 & 0.43 & -14.31 & 0.00 & 0.00 & 0.00 & 0.00 \\
\hline Zone of residence [Urban] & -0.71 & 0.28 & -2.55 & 0.49 & 0.29 & 0.87 & 0.01 \\
\hline Physical violence [Yes] & 0.87 & 0.39 & 2.23 & 2.39 & 1.18 & 5.52 & 0.03 \\
\hline Sexual violence [Yes] & -1.73 & 0.61 & -2.86 & 0.18 & 0.04 & 0.49 & 0.00 \\
\hline Recurrence of violence [Yes] & 1.34 & 0.33 & 4.04 & 3.82 & 1.89 & 7.04 & 0.00 \\
\hline Aggression by cutting object [Yes] & 0.84 & 0.30 & 2.81 & 2.32 & 1.25 & 4.07 & 0.01 \\
\hline Aggression by firearm [Yes] & 1.80 & 0.31 & 5.78 & 6.05 & 3.17 & 10.84 & 0.00 \\
\hline
\end{tabular}

IC = Confidence interval; $O R=$ Odds ratio.

\section{DISCUSSION}

The results of this study made it possible to identify the characteristics of violence against women and homicides in Pernambuco, in addition to noting that the chances of homicide were greater in women who suffered physical violence, agression by cutting object (melee weapon) or firearm and in cases where there was a recurrence of violence. According to the Atlas of Violence of the year 2020, the state of Pernambuco was in the ranking of the Federation Units with the highest homicide rates ${ }^{(12)}$. A study that compared the rates of female homicides in Pernambuco and Brazil observed that the probability of a woman dying in the state is $70 \%$ higher than the national average in the period analyzed ${ }^{(18)}$.

Analysis of the map of female homicides in the mesoregions of Pernambuco showed that the highest rates are located in the Metropolitan Region of Recife, where most of the population lives, where most of the protective equipment and services are located ${ }^{(18)}$. The equipment that makes up the network of protection against violence includes police, justice, health and social assistance, which are more accessible in urban areas ${ }^{(19)}$.

In Brazil, women's police stations and shelters are unevenly distributed, being more present in the capitals and metropolitan regions, something that hinders the effectiveness of such services to combat violence in a uniform manner among municipalities ${ }^{(20)}$. A study on violence against women in Rio Grande do Sul identified factors that could limit women in rural areas from breaking the cycle of violence, such as: distance between rural areas and care and protective services; restricted access to transportation; dependence on partners; little attention from professionals in the care of victims; and disarticulation of the care network ${ }^{(21)}$.
The main characteristics of the homicides were young women, black/brown, unmarried, occurring on public roads and with the use of the firearm. Women's homicides often constitute the outcome of a process of violence suffered by these women, and a significant portion of these homicides are composed of femicides $^{(13)}$. Research on this type of crime in Brazil has shown an upward trend since 2016, and firearms accounted for about half of the deaths ${ }^{(22)}$. In the city of Porto Alegre (RS), in $83 \%$ of femicides, there was a history of previous violence, half of the deaths were caused by gunfire, and $50 \%$ of the victims had denounced the aggressor with the report $\operatorname{card}^{(23)}$.

Among the factors associated with women's homicides is physical violence. This, in most cases, is preceded by/simultaneous to psychological violence, which, in many cases, is not recognized by the victim or is not in itself a reason to seek medical attention ${ }^{(24)}$. A study conducted with women from victims of domestic violence assisted in a specialized service in the municipality of Vitória de Santo Antão (PE), identified that $85.26 \%$ had suffered psychological violence; and $48.08 \%$, physical violence ${ }^{(25)}$. A study on homicide characteristics related to domestic violence showed that $60.2 \%$ of domestic homicide victims had a history of intimate partner violence and that $5.7 \%$ of victims were assaulted in the month preceding their death ${ }^{(26)}$. Another study of homicides with a history of violence, which used police data, identified that $61 \%$ of them occurred due to domestic violence or had a previous history of aggression $^{(27)}$.

The health services are responsible for receiving and carrying out assistance measures and not only medicating injuries or fractures resulting from violence ${ }^{5,28)}$. It is also necessary to articulate the notification of violence against women with counseling and the 
possibility of referral to the network composed of the other care and protection services, in order to end the cycle of violence ${ }^{(29)}$.

The recurrence of violence was one of the main factors associated with the homicides found in this study. The history of aggression often has as an outcome the homicide of these women, which are predicted and avoidable deaths ${ }^{(30)}$. Recent research conducted in Brazil involving 800,000 notifications of violence against women and 16,500 deaths of women linked to it showed that those exposed to violence present a mortality risk eight times higher than the general female population, with emphasis on physical violence and violence involving repetition $^{(31)}$.

The analysis of the risk of lethality among women victims of violence by intimate partner cared for in emergency services showed that $33.1 \%$ had a high risk of death by aggression ${ }^{\text {(32) }}$. Those treated in emergencies as victims of violence make up a priority group for the women's protection network that offers opportunities for interventions and prevention of possible homicides.

Recently, a meta-analysis of risk factors related to homicides of women by an intimate partner identified as a risk factor having a history of previous threat and aggression. If the assailant had already threatened the victim with a gun or if the perpetrator had already strangled the victim in a non-fatal manner, the probability of homicide increased approximately sevenfold ${ }^{(33)}$. About one in ten intimate partner homicide victims experienced some form of violence in the previous month, which could have provided opportunities for intervention ${ }^{(34)}$.

Aggression by means of a firearm was the main factor associated with the homicide of women. Considering the potential for lethality, the use of a firearm can indicate the premeditation of causing the woman's death ${ }^{(35)}$. Aggression by cutting object was also one of the factors found in the study. The use of penetrating, sharp or blunt objects in female homicides indicates greater interpersonal contact, being used because they are close to the aggressor at the time of the conflict and do not reflect the premeditation involved in the firearm ${ }^{(36)}$. Analysis of the homicides of men and women, based on data from the Petrolina Institute of Forensic Medicine (PE), showed that, for both sexes, there was a predominance of perforating or blunt objects, however women were assaulted with more injuries in the thorax and abdomen regions ${ }^{(35)}$. The characteristics of these lesions may be related to gender issues and are suggestive of femicide ${ }^{(35)}$.
Murder is the most serious consequence of violence against women. The characteristics and factors associated with this crime identified in the study are suggestive of gender-based violence, and an expressive portion can be feminicide. The results of the study can contribute to strategies to prevent violence against women and to protect them.

\section{Study limitations}

One limitation of this study is the quality of the secondary data analyzed. In relation to homicides, there may be problems in filling out death certificates, basic cause coding and underreporting. Moreover, with the MIS data, it is not possible to identify the femicides. Regarding violence, consider underreporting. The study includes only those women who revealed that their injury was the result of an aggression, so the risk for women who did not report the aggression as a cause is unknown.

\section{Contributions to the Health Area}

The results of this study can be used to assist in the formulation of public policies to protect women and prevent violence against them. Furthermore, the identification of factors associated with homicide is important for health surveillance actions, as well as for other services of the intersectoral network.

\section{CONCLUSIONS}

It was identified that the factors associated with the homicides of women were: being a victim of physical violence, aggression by cutting object, aggression by firearm and recurrence of violence. The risk of being a victim of homicide was higher for women who suffered aggression by firearms and for those who suffered repetitive violence. The identification of factors associated with homicide is important for health surveillance actions, as well as for other services of the intersectoral network.

\section{FUNDING}

This work was carried out with the support of the Coordination of Improvement of Higher Level Personnel - Brazil (CAPES) - Funding Code 001.

\section{REFERENCES}

1. Krahé B. Violence against women. Curr Opin Psychol [Internet]. 2018 [cited 2019 Feb 6];19:6-10. Available from: https://www.sciencedirect. com/science/article/pii/S2352250X17300489?via\%3Dihub

2. Gregory A, Feder G, Williamson E. The shared burden of domestic violence: a qualitative study with informal supporters of survivors. Lancet [Internet]. 2016[cited 2019 Feb 6];388:S52. Available from: https://www.sciencedirect.com/science/article/pii/S0140673616322887

3. Organização das Nações Unidas (ONU). Agenda 2030: os 17 Objetivos de Desenvolvimento Sustentável [Internet]. 2015[cited 2019 Feb 6]. Available from: http://www.agenda2030.org.br/ods/5/

4. Keller SN, Honea JC. Navigating the gender minefield: an IPV prevention campaign sheds light on the gender gap. Glob Public Health [Internet]. 2016 [cited 2019 Feb 6];11(1-2):184-97. Available from: http://www.tandfonline.com/doi/full/10.1080/17441692.2015.1036765

5. Oliveira RNG, Fonseca RMGS, Oliveira RNG, Fonseca RMGS. Health needs: the interface between the discourse of health professionals and victimized women. Rev Latino-Am Enfermagem. 2015;23(2):299-306. https://doi.org/10.1590/0104-1169.3455.2555 
6. Oram S, Khalifeh H, Howard LM. Violence against women and mental health. Lancet Psychiatr [Internet]. 2017[cited 2019 Feb 6];4(2):159-70. Available from: https://linkinghub.elsevier.com/retrieve/pii/S2215036616302619

7. World Health Organization (WHO). Addressing violence against women: key achievements and priorities [Internet]. 2018 [cited 2019 Feb 6]. Available from: https://apps.who.int/iris/bitstream/handle/10665/275982/WHO-RHR-18.18-eng.pdf

8. Jayachandran S. The roots of gender inequality in developing countries. Ann Rev Econom [Internet]. 2014[cited 2019 Feb 6];7:63-8. Available from: https://faculty.wcas.northwestern.edu/ sjv340/roots_of_gender_inequality.pdf

9. Fidan A, Bui HN. Intimate partner violence against women in Zimbabwe. Violence Against Women [Internet]. 2016;22(9):1075-96. Available from: http://journals.sagepub.com/doi/10.1177/1077801215617551

10. Dawson M, Carrigan M. Identifying femicide locally and globally: understanding the utility and accessibility of sex/gender-related motives and indicators. Curr Sociol [Internet]. 2020;001139212094635. Available from: http://journals.sagepub.com/doi/10.1177/0011392120946359

11. Organização das Nações Unidas (ONU). Global Study on Homicide: 2019 [Internet]. 2019[cited 2019 Feb 6]. Available from: https://www. unodc.org/documents/data-and-analysis/gsh/Booklet_5.pdf

12. Instituto de Pesquisa Econômica Aplicada (IPEA) Atlas da Violência: 2020 Relatório Inst [Internet]. 2020[cited 2019 Feb 6]. Available from: https://www.ipea.gov.br/atlasviolencia/

13. Höfelmann DA, Silva GDM, Freitas LSR. Estimativas corrigidas de feminicídios no Brasil: 2009 a 2011. Rev Panam Salud Pública [Internet]. 2015[cited 2019 Feb 6];37(4/5):251-7. Available from: https://scielosp.org/article/rpsp/2015.v37n4-5/251-257/\#metric_modal_id

14. Instituto Brasileiro de Geografia e Estatística. Sistema IBGE de Recuperação Automática - SIDRA [Internet]. 2019[cited 2019 Feb 6]. Available from: https://sidra.ibge.gov.br/home/pmc/brasil

15. Sayers A, Ben-Shlomo Y, Blom AW, Steele F. Probabilistic record linkage. Int J Epidemiol [Internet]. 2016[cited 2019 Feb 6];45(3):954-64. Available from: https://academic.oup.com/ije/article-lookup/doi/10.1093/ije/dyv322

16. Paixão ES, Harron K, Andrade K, Teixeira MG, Fiaccone RL, Costa MCN, et al. Evaluation of record linkage of two large administrative databases in a middle income country: stillbirths and notifications of dengue during pregnancy in Brazil. BMC Med Inform Decis Mak [Internet]. 2017[cited 2019 Feb 6];17(1):108. Available from: http://bmcmedinformdecismak.biomedcentral.com/articles/10.1186/s12911-017-0506-5

17. Abath MB, Lima MLLT, Lima PS, Silva MCM, Lima MLC. Avaliação da completitude, da consistência e da duplicidade de registros de violências do Sinan em Recife, Pernambuco, 2009-2012. Epidemiol e Serviços Saúde [Internet]. 2014[cited 2019 Feb 6];23(1):131-42. Available from: http://scielo.iec.gov.br/pdf/ess/v23n1/v23n1a13.pdf

18. Araújo LGM, Melo MGF, Vieira MEA. Mapa dos homicídios femininos nas Mesorregiões de Pernambuco. e-hum [Internet]. 2019 [cited 2019 Feb 6];10(2):29-37. Available from: https://unibh.emnuvens.com.br/dchla/article/view/2154

19. Borth LC, Costa MC, Silva EB, Fontana DGR, Arboit J. Network to combat violence against rural women: articulation and communication of services. Rev Bras Enferm. 2018;71(suppl 3):1212-9. https://doi.org/10.1590/0034-7167-2017-0044

20. Instituto de Pesquisa Econômica Aplicada (IPEA). Avaliando a efetividade da Lei Maria Da Penha[Internet]. 2015[cited 2019 Feb 6]. Available from: http://repositorio.ipea.gov.br/bitstream/11058/3538/1/td_2048.pdf

21. Costa MC, Silva EB, Soares JSF, Borth LC, Honnef F. Mulheres rurais e situações de violência: fatores que limitam o acesso e a acessibilidade à rede de atenção à saúde. Rev Gaúcha Enferm. 2017;38(2):e59553. https://doi.org/10.1590/1983-1447.2017.02.59553

22. Roichman CBC. Knife, carver, jackknife: an analysis of the femicide law in Brazil. Rev Katálysis. 2020;23(2):357-65. Available from: https://doi. org/10.1590/1982-02592020v23n2p357

23. Margarites AF, Meneghel SN, Ceccon RF. Feminicídios na cidade de Porto Alegre: quantos são? quem são? Rev Bras Epidemiol. 2017;20(2):225-36. https://doi.org/10.1590/1980-5497201700020004

24. Sousa AKA, Nogueira DA, Gradim CVC. Perfil da violência doméstica e familiar contra a mulher em um município de Minas Gerais, Brasil. Cad Saúde Coletiva [Internet]. 2013 [cited 2019 Feb 6];21(4):425-31. Available from: http://www.scielo.br/scielo. php?script=sci_arttext\&pid=S1414-462X2013000400011\&lng=pt\&tlng=pt

25. Lima EAC, Araújo AA, Lima AWS, Costa GM, Barros MBSC, Santos ZC. "Afasta de mim esse cale-se!": mulheres vítimas de violência doméstica e familiar em um município de Pernambuco. Enferm Bras [Internet]. 2019 [cited 2019 Feb 6];18(1):42. Available from: http://www. portalatlanticaeditora.com.br/index.php/enfermagembrasil/article/view/2384

26. Jiang Y, DeBare D, Shea L-M, Viner-Brown S. Violence Against Women: Injuries and Deaths in Rhode Island, 2013 [Internet]. 2017 [cited 2019 Feb 6];100(12):24-8. Available from: http://europepmc.org/abstract/MED/29190839

27. Iratzoqui A, McCutcheon J. The influence of domestic violence in homicide cases. Homicide Stud [Internet]. 2018 [cited 2019 May 1];22(2):145-60. Available from: http://journals.sagepub.com/doi/10.1177/1088767917751673

28. Taft A, O'Doherty L, Hegarty K, Ramsay J, Davidson L, Feder G. Screening women for intimate partner violence in healthcare settings. In: Taft A, editor. Cochrane Database of Systematic Reviews [Internet]. Chichester, UK: John Wiley \& Sons, Ltd; 2013. http://doi.wiley. com/10.1002/14651858.CD007007.pub2

29. Barufaldi LA, Souto RMCV, Correia RSB, Montenegro MMS, Pinto IV, Silva MMA, et al. Violência de gênero: comparação da mortalidade por agressão em mulheres com e sem notificação prévia de violência. Cienc Saude Colet. 2017;22(9):2929-38. https://doi. org/10.1590/1413-81232017229.12712017 
30. Meneghel SN, Portella AP, Meneghel SN, Portella AP. Feminicídios: conceitos, tipos e cenários. Cienc Saude Colet. 2017;22(9):3077-86. https://doi.org/10.1590/1413-81232017229.11412017

31. Sandoval GA, Marinho F, Delaney R, Pinto IV, Lima CMD, Costa RM, et al. Mortality risk among women exposed to violence in Brazil: a population-based exploratory analysis. Public Health [Internet]. 2020 [cited 2019 Feb 6];179:45-50. Available from: https://linkinghub. elsevier.com/retrieve/pii/S0033350619303117

32. Brignone L, Gomez AM. Double jeopardy: predictors of elevated lethality risk among intimate partner violence victims seen in emergency departments. Prev Med (Baltim) [Internet]. 2017 [cited 2019 Feb 6];103:20-5. Available from: https://www.sciencedirect.com/science/article/ pii/S0091743517302396?via\%3Dihub

33. Spencer CM, Stith SM. Risk Factors for Male Perpetration and Female Victimization of Intimate Partner Homicide: A Meta-Analysis. Trauma, Violence, Abus [Internet]. 2018 [cited 2019 Feb 6];152483801878110. Available from: http://journals.sagepub.com/ doi/10.1177/1524838018781101

34. Petrosky E, Blair JM, Betz CJ, Fowler KA, Jack SPD, Lyons BH. Racial and ethnic differences in homicides of adult women and the role of intimate partner violence: United States, 2003-2014. MMWR Morb Mortal Wkly Rep [Internet]. 2017 [cited 2019 Feb 6];66(28):741-6. Available from: http://www.cdc.gov/mmwr/volumes/66/wr/mm6628a1.htm

35. Campos MEAL, Brasil AANS, Silva EFS, Fernandes FECV. Mortalidade por homicídio a partir de dados do Instituto de Medicina Legal: uma perspectiva de gênero. Rev Bras Pesqui Saúde [Internet]. 2019 [cited 2019 Feb 6];21(3):93-102. Available from: http://periodicos.ufes.br/ rbps/article/view/28213

36. Boivin RR. Características y factores de la violencia homicida contra las minorías sexuales en la Ciudad de México, 1995-2013. Sex Salud Soc (Rio J). 2016;(23):22-57. Available from: https://doi.org/10.1590/1984-6487.sess.2016.23.02.a 